\title{
Sperm storage and morphofunctional bases of the female reproductive tract of the snake Philodryas patagoniensis from southeastern Brazil
}

\author{
Claudio Augusto Rojas ${ }^{1}$ - Verônica Alberto Barros ${ }^{2}$ Selma Maria Almeida-Santos ${ }^{1}$
}

Received: 19 June 2015/Revised: 31 August 2015/Accepted: 3 September 2015/Published online: 6 October 2015

(C) Springer-Verlag Berlin Heidelberg 2015

\begin{abstract}
Macroscopic and microscopic examination of the female reproductive tract of Philodryas patagoniensis was conducted in order to observe sperm storage structures and determine morphological changes throughout the reproductive cycle. The oviduct of $P$. patagoniensis is composed of the infundibulum (anterior and posterior), uterus, utero-vaginal junction, and vagina. The uterine epithelium showed constant secretory activity throughout the reproductive cycle, although increased production of secretory granules was observed in secondary vitellogenic females. Sperm storage occurs in the posterior infundibulum and utero-vaginal junction in pregnant, primary (postpartum), and secondary vitellogenic females. These data suggest that $P$. patagoniensis may be able to produce several clutches from a single mating. Sperm storage in the posterior infundibulum occurs in sperm receptacles, while in the utero-vaginal junction sperm is stored in crypts. Histochemical tests by periodic acid-Schiff revealed that both sperm storage sites increase the production of neutral carbohydrate-rich granules in the presence of sperm, similar to snakes from temperate regions. This is the first report of sperm storage in the posterior infundibulum of a neotropical snake.
\end{abstract}

Communicated by A. Schmidt-Rhaesa.

Claudio Augusto Rojas

dipsas@hotmail.com

1 Laboratory of Ecology and Evolution, Butantan Institute, 1500 Vital Brasil Avenue, São Paulo, SP 05503-000, Brazil

2 Animal Biology Postgraduate Programme, São Paulo State University (UNESP), 2265 Cristovão Colombo Street, São José do Rio Preto, SP 15054-000, Brazil
Keywords Dipsadidae · Oviduct · Histology · Histochemical reaction - Scanning electron microscopy

\section{Introduction}

The anatomical terminology for oviductal regions and their functions are controversial issues in reptiles' anatomy. In general, the oviduct is divided into five different regions: infundibulum, uterine tube, isthmus, uterus, and Giacomini's diverticulum or vagina (Girling 2002). Various descriptions of the oviduct divide the infundibulum and the uterus into anterior and posterior portions in squamates (snakes, lizards, and amphisbaenians) (Aldridge 1992; Blackburn 1998; Almeida-Santos and Orsi 2002). Recently, Siegel and Sever (2008a, b) proposed the division of the uterus into nonglandular and glandular portions for snakes. The nonglandular portion has already been named anterior vagina and vagina (Fox 1956; Blackburn 1998). Others terms (pouch and vaginal pouch) were also proposed for the vagina (Ludwig and Rahn 1943; Gabe and Saint-Girons 1965; Blackburn 1998; Siegel et al. 2011). However, the terminology of oviductal portions should be revised considering the function of each part and the origin of the word to avoid misunderstandings and provide an easier recognition of each region.

The reptilian oviduct has diverse reproductive functions (see Girling 2002) including sperm storage, which is undoubtedly the most intriguing. Among squamates, the location of sperm storage structures in the oviducts is similar in snakes and lizards: they can be found in the posterior infundibulum, posterior uterus, and vagina (Fox 1956, 1963; Saint-Girons 1962; Halpert et al. 1982; Sever and Hamlett 2002; Barros et al. 2012, 2014a, b). Sperm storage in the posterior uterus and vagina may occur in 
glands (Sever and Ryan 1999; Sever and Hamlett 2002) or in deep furrows (crypts), as described for the rattlesnake Crotalus durissus and some bothropoid species (AlmeidaSantos and Salomão 1997, 2002; Barros et al. 2012, 2014a). In the posterior infundibulum, sperm storage occurs in structures constituted by glands (simple or compound tubular and branched alveolar) that communicate with sperm receptacles (SR) (Fox 1956; Siegel et al. 2011).

Phenomena occurring while sperm is stored in different oviductal sites are a polemic question. Although some authors argue that oviductal regions function only as a physical refuge (Sever and Ryan 1999; Sever and Hamlett 2002), others present evidence that oviductal secretion provides a chemical refuge and nourishment site for stored sperm (Fox 1956; Hoffman and Wimsatt 1972; Halpert et al. 1982; Marinho et al. 2009). Presently, most of the knowledge on oviductal morphophysiology and reproductive tactics of snakes comes from studies on species of temperate regions (Aldridge and Duvall 2002; Aldridge et al. 2009), with the exception of some research conducted in South America, mainly with pit vipers (Almeida-Santos and Salomão 1997, 2002; Barros et al. 2012, 2014a, b). However, all these studies in the neotropics did not consider or fail to find infundibular sperm storage in these species. Considering that recent findings show that squamates display interspecific and intraspecific variation in reproductive tactics (Mesquita and Colli 2003; Carretero 2006; Ribeiro et al. 2010; Garda et al. 2012; Barros et al. 2012, 2014a, b) and that environmental conditions are highly different between temperate and tropical regions, would sperm storage patterns also differ among species from the temperate and tropical regions? Would the pattern and function of oviductal secretions show differences among different lineages of snakes? Data on sperm storage of several species are necessary to establish a comprehensive pattern for snakes and thus answer these questions. Here, we provide a contribution to this theme, focusing on the study of the female reproductive tract of Philodryas patagoniensis (Girard, 1858), a neotropical oviparous snake species that would probably show sperm storage due to the dissociation between timing of mating in winter (Travaglia-Cardoso et al., unpublish. data) and ovulation in spring (Fowler et al. 1998). This snake belongs to Dipsadidae and is widely distributed in South America throughout Argentina, Brazil, Paraguay, eastern Bolivia, and Uruguay (Thomas 1976; Giraudo and Scrocchi 2002). Populations from southeastern Brazil show seasonal reproductive cycle with ovulation restricted to spring, oviposition, and hatching of newborns in summer (Fowler et al. 1998). The aims of this study are to address the existence of sperm storage structures in different oviductal portions of $P$. patagoniensis and investigate the nature of the secretion produced throughout the reproductive cycle and while sperm storage occurs. We also compare the anatomy of the female reproductive tract of $P$. patagoniensis and propose an adjustment in the nomenclature for oviductal portions of snakes including the use of the term utero-vaginal junction (UVJ). This term has already been used for lizards (Sever and Hamlett 2002), birds (Bakst 1987), and turtles (Gist and Congdon 1998).

\section{Materials and methods}

\section{Specimens}

We examined a total of 20 specimens of $P$. patagoniensis from the southeastern region of Brazil. Individuals originated from the states of São Paulo $\left(23^{\circ} 09^{\prime}-23^{\circ} 27^{\prime} \mathrm{S}\right.$; $\left.46^{\circ} 31^{\prime}-47^{\circ} 03^{\prime} \mathrm{W}\right)$ and Minas Gerais $\left(18^{\circ} 55^{\prime}-19^{\circ} 07^{\prime} \mathrm{S}\right.$; $\left.44^{\circ} 19^{\prime}-48^{\circ} 16^{\prime} \mathrm{W}\right)$. Seven of these snakes were held in a zoological collection in Minas Gerais (Fundação Ezequiel Diaz-FUNED), and thirteen specimens were received and euthanized at Instituto Butantan (São Paulo City) from 2009 to 2012. Individuals were euthanized by an intracoelomic injection of thionembutal $(30 \mathrm{mg} / \mathrm{Kg})$, followed by a $0.2-\mathrm{ml}$ intracardiac injection of potassium chloride $(\mathrm{KCl})$ (Rojas et al. 2013). The left side of the reproductive tract was removed and fixed in $4 \%$ paraformaldehyde solution, for no less than $48 \mathrm{~h}$, for light microscopy. The right oviduct was removed and fixed in $2.5 \%$ glutaraldehyde, for no less than $48 \mathrm{~h}$, for examination with scanning electron microscopy (SEM). Tissue samples of animals from FUNED were used only for analysis for light microscopy. This work is in agreement with the Ethical Principles in Animal Research, adopted by the Brazilian College of Animal Experimentation, and it was approved by the Ethical Committee for Animal Research of Butantan Institute (protocol number 668/09).

\section{Light microscopy methods}

Samples were processed by historesin (Glycol methacrylate-Leica) and paraffin (Petrobrás) methods (Junqueira et al. 1979; Junqueira 1995). Sections 2 and $5 \mu \mathrm{m}$ thick were cut for historesin and paraffin, respectively. Histological staining methods used were hematoxylin and eosin (H\&E) in paraffin (Junqueira et al. 1979) and toluidine blue-fuchsin $(\mathrm{T} \& \mathrm{~F})$ for sections in historesin (Junqueira 1995). To determine possible variations in the secretory activity of the oviducts during different phases of the reproductive cycle, including the sperm storage process, the sections were submitted to the following histochemical reactions in both the methacrylate (historesin) and paraffin: bromophenol blue (BB) for protein identification, periodic 
acid-Schiff (PAS) for identification of neutral carbohydrates, and alcian blue (AB) $\mathrm{pH} 2.5$ for carboxylated glycosaminoglycans. Slides were viewed using an Olympus BX51 microscope, and images were obtained via ImagePro Express Olympus Program.

\section{Scanning electron microscopy methods}

The tissues were fixed in $2.5 \%$ glutaraldehyde, rinsed in $0.1 \mathrm{M}$ sodium phosphate buffer ( $\mathrm{pH} 7.2$ ), and then postfixed $90 \mathrm{~min}$ in $1 \%$ osmium tetroxide. After a rinse in $0.1 \mathrm{M}$ sodium phosphate buffer $(\mathrm{pH} 7.2)$ and distilled water, the tissues were incubated in $1 \%$ tannin for $1 \mathrm{~h}$ and dehydrated with a graded series of ethanol $(50,70,90$, and $100 \%$ for $10 \mathrm{~min}$ each). Lastly, the dehydrated tissues were coated with gold and examined with a Zeiss LEO 435 VP scanning electron microscope (Leo Electron Microscopy Ltd Corporation Zeiss Leica, Cambridge, England), operating between 15 and $25 \mathrm{kV}$.

\section{Results}

\section{Gross morphology}

The reproductive tract of $P$. patagoniensis consists of two paired ovaries and oviducts, with the right side of the reproductive system situated more cranial than the left. The oviduct has four different regions (Fig. 1). The most cranial region of the female reproductive tract is the folded and translucent infundibulum. The infundibulum is divided into anterior and posterior portions. The anterior portion of the infundibulum is funnel-shaped and more translucent than the posterior infundibulum (Fig. 1, region 1). After the posterior infundibulum, there is a flaccid structure responsible for egg incubation during pregnancy: the uterus, which is the longest region of the oviducts (Fig. 1, region 2). Subsequent to the uterus, we observe the UVJ, a region characterized by its thinner tissue, smaller diameter, and the easy identification in pregnant females (Fig. 1, region 3). The UVJ connects to the vagina, which is merged into the cloaca, and thus cannot be seen with the naked eye (Fig. 1, region 4).

\section{Microscopy morphology and oviductal secretory activity}

Microscopic analysis of the oviduct showed clearer the divisions between different regions in comparison with gross morphology. The infundibulum is a folded structure with simple columnar to cuboidal epithelium constituted by ciliated cells and secretory cells with microvilli (Fig. 2a, b). The division of the anterior and posterior regions of the

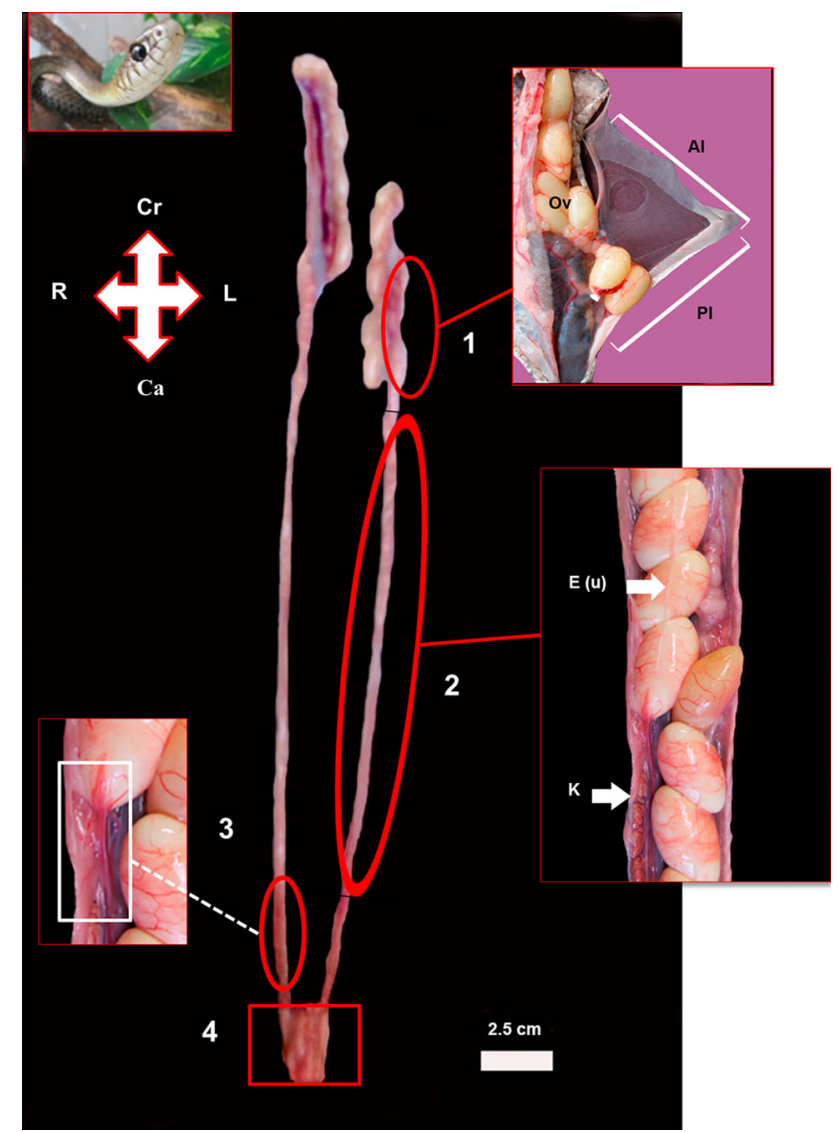

Fig. 1 Gross morphology of the female reproductive tract of $P$. patagoniensis. 1 Infundibulum, 2 uterus, $3 \mathrm{UVJ}, 4$ cloaca. $A I$ anterior infundibulum, $\mathrm{Ca}$ caudal, $\mathrm{Cr}$ cranial, $E(u)$ eggs into the uterus, $K$ kidney, $L$ left, $O v$ ovaries, $P I$ posterior infundibulum, $R$ right

infundibulum is marked by the appearance of compound tubular ciliated glands (Fig. 2c). This kind of gland is abundant in the posterior infundibulum, and its terminal portion functions as a sperm receptacle (SR) (Fig. 2c, d). The initial portion of these glands may also house sperm for a short period of time, and the sperm receptacles are surrounded by myoid cells (Fig. 2d). Females collected during summer and spring (including pregnant females) showed sperm stored in the SR (Fig. 2c-e). Groups of stored spermatozoa exhibited parallel alignment, and their heads come in contact with the epithelium of the SR (Fig. 2d, e). The epithelium of receptacles is cuboidal although its height may vary according to sperm density. Histochemical tests (PAS) revealed that sperm receptacles increase the production of neutral carbohydrate-rich granules in the presence of sperm (Fig. 2e). Histochemical reaction to $\mathrm{AB}$ and $\mathrm{BB}$ was weak, indicating low activity for carboxylated glycosaminoglycans (acids) and proteins, respectively.

The uterus, where pregnancy occurs, is a folded structure that presents a thicker lamina propria and muscular layer than the posterior infundibulum (Fig. 2f). This 

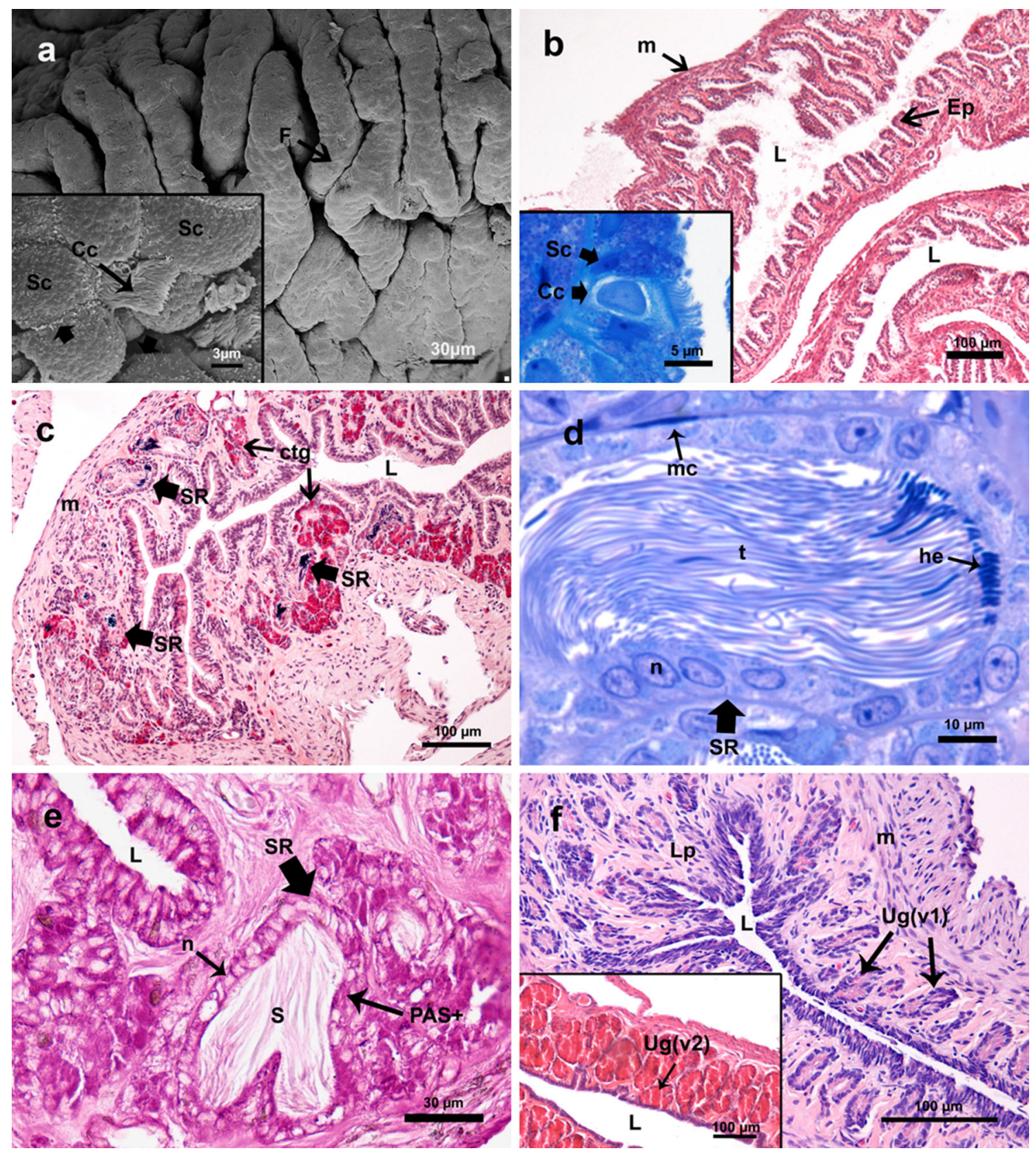

Fig. 2 Photomicrograph of the infundibulum and uterus of $P$. patagoniensis. a SEM of infundibular luminal epithelium characterized as a folded structure. Inset Ciliated and secretory cells with microvilli (small black arrows). b Cross section of anterior infundibulum (stained H\&E). Inset Higher magnification of luminal epithelium (stained T\&F). c Transverse section of posterior infundibulum with presence of numerous SR. d Higher magnification of SR (T\&F). e SR with positive reaction for PAS. $\mathbf{f}$ Cross section of uterus in primary vitellogenic female with tubular uterine glands

portion of the oviduct is constituted mainly by tubular uterine glands with basal nuclei and eosinophilic cytoplasmic granules (Fig. 2f inset). During secondary vitellogenesis (August-December), the size of uterine glands increases and fills the lamina propria of the mucosa (for a
$(\mathrm{H} \& \mathrm{E})$. Inset Increase in uterine glands in secondary vitellogenic female. $C c$ ciliated cells, ctg compound tubular ciliated glands, Ep luminal epithelium, $F$ folds, $h e$ spermatozoa head, $L$ lumen, $L p$ lamina propria, $m$ muscular layer, $m c$ myoid cells, $n$ nuclei, $S$ spermatozoa, $S c$ secretory cells, $S R$ sperm receptacle, $P A S+$ positive reaction to periodic acid-Schiff, $t$ spermatozoa tail, $U g(v l)$ uterine glands in primary vitellogenesis, and $U g(v 2)$ uterine glands in secondary vitellogenesis

comparison to females in primary vitellogenesis, see Fig. $2 \mathrm{f}$ inset). The uterine luminal epithelium is composed of ciliated and secretory cells (Fig. 3a). Positive histochemical reactions for $\mathrm{AB}$ and PAS occurred in the apical portion of the cells throughout the year (Fig. 3b). However, 

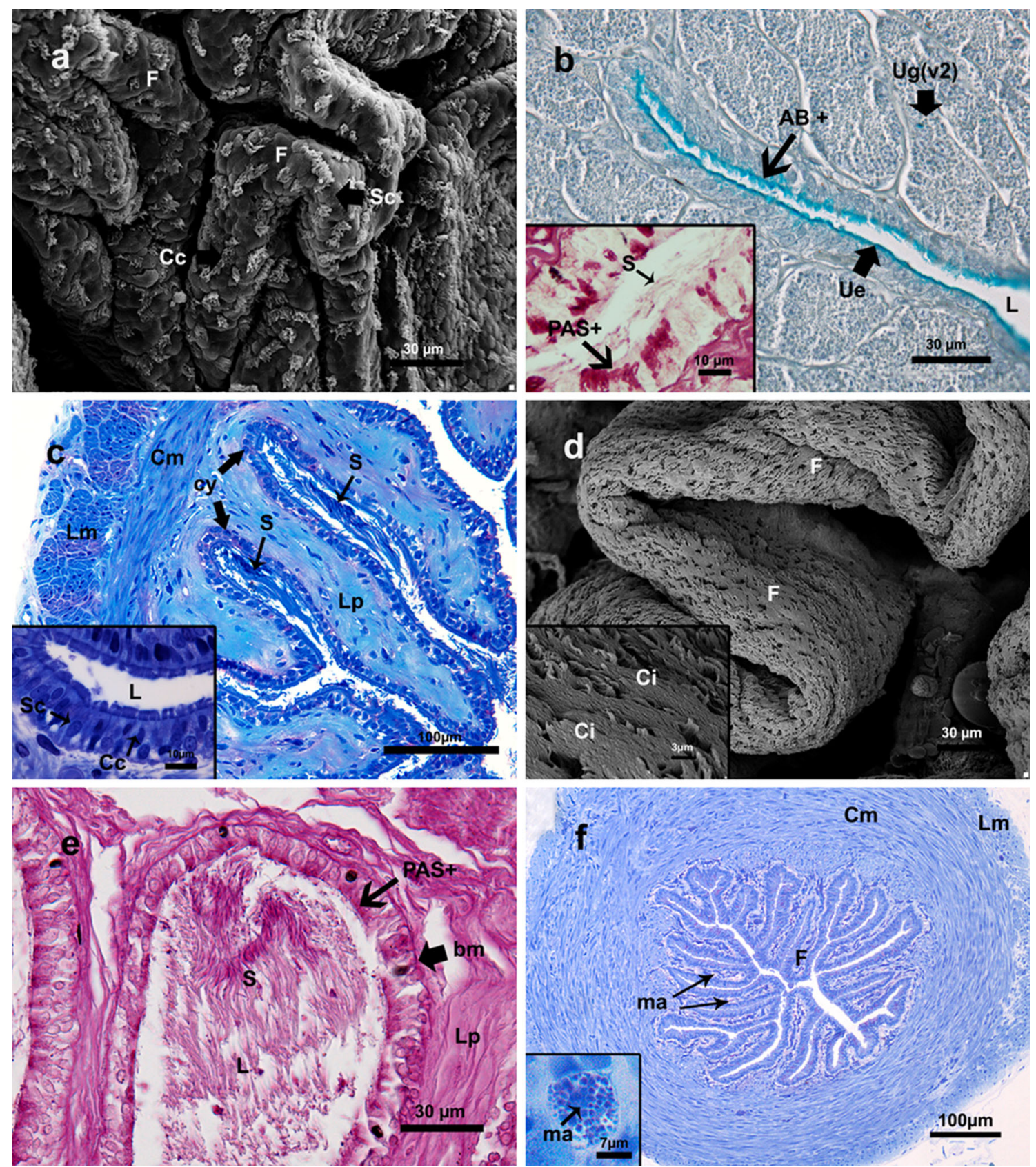

Fig. 3 Cross section of the uterus, UVJ, and vagina in $P$. patagoniensis. a SEM of the uterine luminal epithelium. b Transverse section of the uterus with positive histochemical reactions for $\mathrm{AB}(\mathrm{pH}$ 2.5 ) in the luminal epithelium. Inset Positive reaction for PAS in the presence of sperm. c Sagittal section showing crypts of the UVJ with presence of sperm from a female collected in summer (stained T\&F). Inset Higher magnification of the luminal epithelium. d SEM of the UVJ. Inset The epithelium lining the lumen shows ciliated cell.

we detected an increase in the secretion of neutral carbohydrates occurring simultaneously to follicular development and the presence of sperm (Fig. $3 \mathrm{~b}$ inset). Uterine tubular glands reacted negatively to $\mathrm{AB}, \mathrm{BB}$ and PAS. The uterine epithelium also exhibited a negative reaction to $\mathrm{BB}$. e Positivity to PAS in the UVJ with production of secretory granules. f Transverse section revealing histology of the vagina (stained T\&F). Inset Mastocyte cells. $A B+$ positive reaction to alcian blue, $b m$ basement membrane, $C c$ ciliated cells, $C i$ cilia, $C m$ circular muscle, $c y$ crypts, $F$ folds, $L$ lumen, $L m$ longitudinal muscle, $L p$ lamina propria, $m a$ mastocyte cells, $P A S+$ positive reaction to periodic acidSchiff, $S$ spermatozoa, $S c$ secretory cells, $U e$ uterine epithelium, and $U g(v 2)$ uterine glands in secondary vitellogenesis

Caudal to the uterus, there is the UVJ characterized by long folds, deep crypts, and a well-developed muscular layer (Fig. 3c, d). We observed two types of smooth musculature: an internal circular layer and an external longitudinal layer (Fig. 3c). The UVJ does not have glands 
in the tunica mucosa, and pregnancy does not occur in this region, which suggests a different function from the uterus. The epithelium is pseudostratified with abundant ciliated cells and some secretory cells (Fig. 3c, d inset). A pregnant female and a female that had oviposited recently in spring/summer showed stored sperm in the UVJ (Fig. 3c). Similar to the posterior infundibulum, the epithelium of the UVJ showed a PAS positivity reaction during sperm storage (Fig. 3e). The division between the UVJ and the vagina is observed mainly by histological analysis because the vagina and cloaca are fused.

The vagina has a thick lamina propria with folds and a well-developed muscular layer (Figs. 3f, 4a). One of the main characteristics for the microscopic identification of the vagina is the presence of abundant mastocyte cells spread through the lamina propria (Fig. 3f inset). The epithelium is pseudostratified columnar with sparse ciliated cells and secretory cells with basophilic granules in the apical portion (Fig. 4b). The production of granules by the secretory cells is constant throughout the year (Fig. 4b). Histochemical analysis of the vagina exhibited positive reactions to neutral carbohydrates and carboxylated
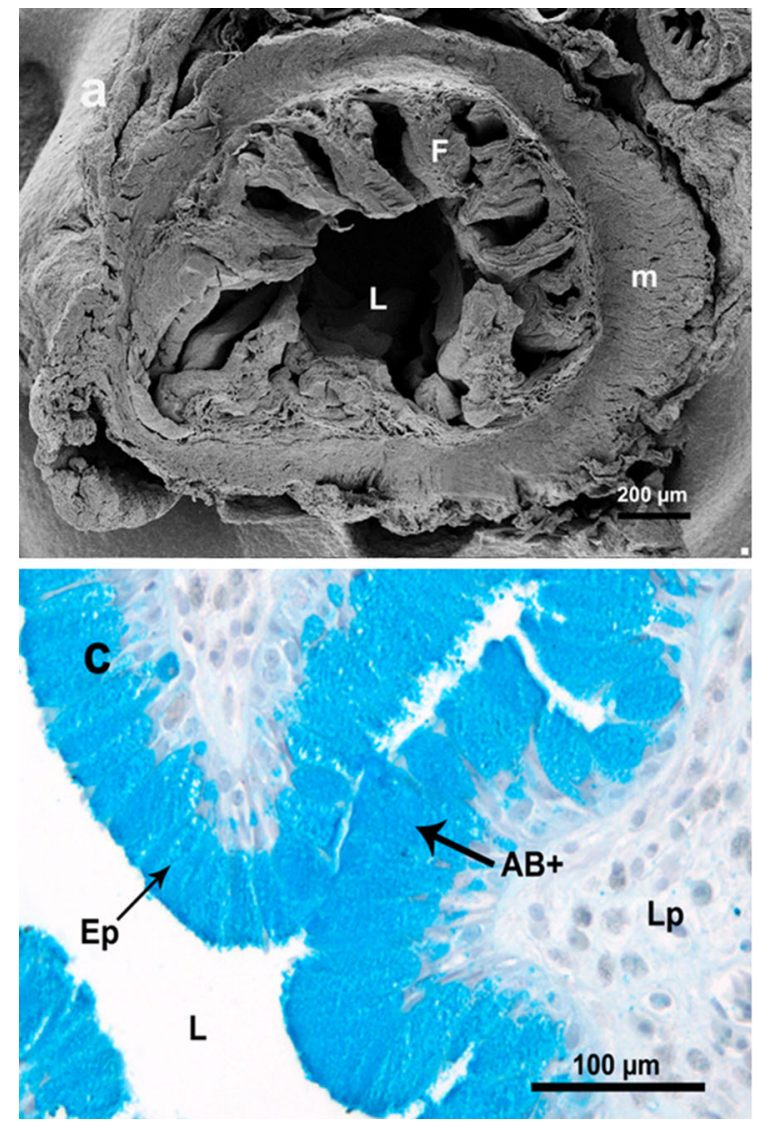

Fig. 4 Transverse section of the vagina in $P$. patagoniensis. a SEM of the vagina. b Light micrograph of vaginal epithelium (stained $\mathrm{H} \& \mathrm{E})$. c Positive reaction for $\mathrm{AB}(\mathrm{pH} 2.5)$ in pregnant female. d Sagittal section of the cloaca (stained T\&F). $A B+$ positive reaction glycosaminoglycans in every snake sampled. However, the reaction for $\mathrm{AB}(\mathrm{pH} 2.5)$ was more intense in pregnant females (Fig. 4c). The presence of sperm in the vagina, which is an indicative of recent mating activity, was not observed in any individual sampled. The cloaca is differentiated from the vagina by its stratified pavimentous epithelium (Fig. 4d).

\section{Discussion}

\section{Morphology and oviductal activity}

Grossly, the oviduct of $P$. patagoniensis showed an asymmetrical pattern like most snake species (Blackburn 1998; Girling 2002; Siegel et al. 2011). This characteristic provides an optimal arrangement of the space in the coelomic cavity during pregnancy (Perkins and Palmer 1996). The different oviductal regions described herein are also similar to other snakes regarding structure and function (Saint-Girons 1957; Bauman and Metter 1977; Mead et al. 1981; Sever et al. 2000; Siegel and Sever 2008a; Barros

b
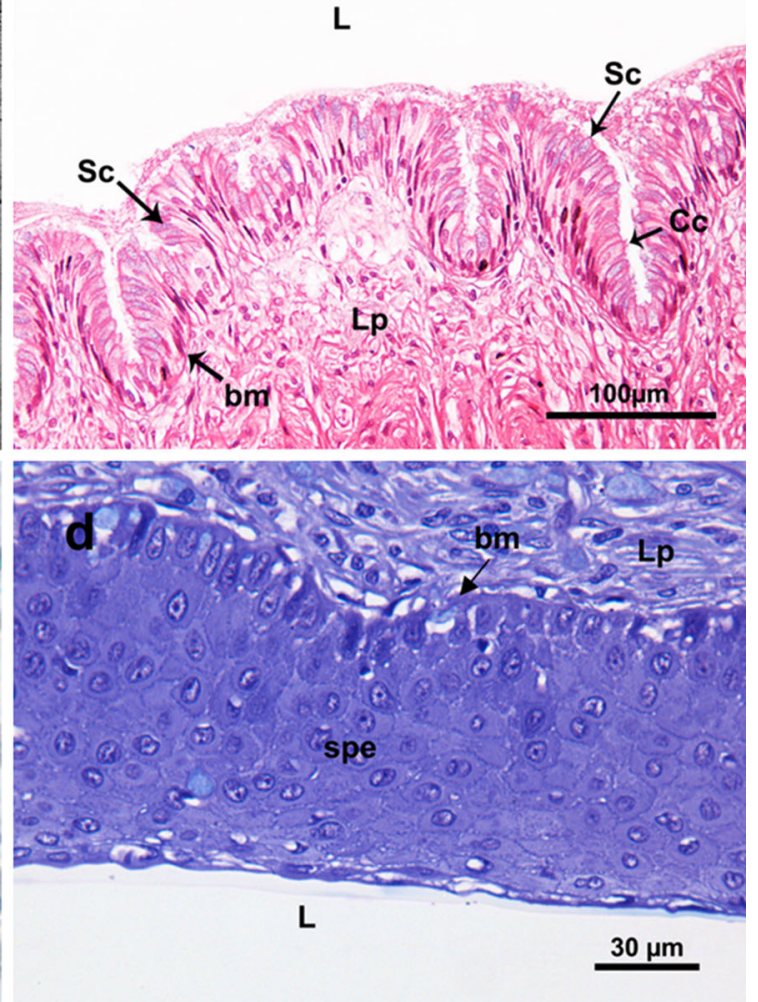

to alcian blue, $C c$ ciliated cells, $E p$ luminal epithelium, $F$ folds, $L$ lumen, $L p$ lamina propria, $m$ muscular layer, $b m$ basement membrane, $S c$ secretory cells, and spe stratified pavimentous epithelium 
et al. 2014b; De Resende and Nascimento 2015). The epithelial cells secrete neutral carbohydrates and carboxylated glycosaminoglycans throughout the reproductive cycle (Gabe and Saint-Girons 1965; Uribe et al. 1998; Sanchez-Martinez et al. 2007; De Resende and Nascimento 2015). This constant secretory activity indicates that they act in the protection against invasive microorganisms, lubrification, and humidity maintenance avoiding the loss of water (Junqueira and Carneiro 2008). However, the intense reaction to $\mathrm{AB}$ in the vagina of pregnant females of $P$. patagoniensis probably occurs due to the presence of glycosaminoglycans. This type of material is present in tissues with high malleability, and it may suggest that these females will oviposit soon (Perkins and Palmer 1996; Heulin et al. 2005).

The increase in the epithelial secretion in secondary vitellogenic females of $P$. patagoniensis during winter and spring may be under the influence of hormones. Several experimental studies reported that the administration of estrogen to females increases the size of uterine glands and oviductal epithelial height (Panigel 1956; Callard et al. 1972; Mead et al. 1981). However, the increase in neutral carbohydrate secretion in certain portions of the oviduct may be linked to sperm storage, as this reproductive tactic occurs in $P$. patagoniensis. This secretory activity has already been described for several snake species (Fox 1956; Saint-Girons 1975; Bauman and Metter 1977; Perkins and Palmer 1996; Sever et al. 2000).

The infundibulum has little morphological differences between the anterior and posterior portions. The anterior infundibulum enfolds the developing oocyte and acts as an entrance door for it (Girling 2002). It is composed mainly by ciliated cells that act in the positioning of the oocyte around the infundibular ostium (Girling 2002). There are also few secretory cells (Girling 2002), which function would be to initiate the formation of the shell membrane (Hoffman 1970). In P. patagoniensis, these secretory cells do not have this function because sperm receptacles are located caudal to the anterior infundibulum (i.e., in the posterior infundibulum). Thus, the deposition of secretory material around the oocyte would be a physical barrier at the timing of fertilization. According to Blackburn (1998), sperm is not able to penetrate the shell membrane; thus, fertilization would occur before the deposition of this material, as observed in chelonians (Gist and Jones 1989) and birds (Bakst and Bahr 1993). The posterior infundibulum is the site for fertilization of the follicles and also the most specialized region of the oviduct in $P$. patagoniensis. It is composed of sperm receptacles that are compound ramified tubular glands (discussed herein in the section about sperm storage).

The uterus has an important role in the development of eggs in oviparous snakes, mainly in formation of the shell membranes (Giacomini 1893; Perkins and Palmer 1996; Girling 2002). Uterine glands of $P$. patagoniensis are similar to those observed in Cerastes cerates, Coniophanes fissidens, Crotalus viridis, Natrix natrix, and Vipera aspis (Siegel et al. 2011). The increase in uterine glands observed in secondary vitellogenic females (compared to primary vitellogenic females) has already been described for other squamates (Heulin et al. 2005). Negative histochemical reactions to $\mathrm{PAS}, \mathrm{AB}$, and $\mathrm{BB}$ for uterine glands in $P$. patagoniensis is different from results described for A. piscivorus ( $\mathrm{PAS}+$ and $\mathrm{BB}+$ ) and $T$. sirtalis $(\mathrm{BB}+$ ) (Hoffman 1970; Siegel and Sever 2008b). The high positivity for PAS and $\mathrm{AB}$ in the uterine epithelium indicates that epithelial secretory granules play a role in the production of the shell membrane, as observed previously (Hoffman 1970; Corso et al. 1988).

Histological and cytological characterization of the UVJ is similar to previous descriptions for other snake species (Blackburn 1998; Girling 2002; Saint-Girons 1957; Perkins and Palmer 1996; Uribe et al. 1998; Siegel and Sever 2008a; Siegel et al. 2011). Nevertheless, the terms vagina and uterus (posterior or nonglandular) are not adequate to designate the UVJ because they are not consistent with the etymology of the word. The term vagina (Latin) means sheath (in general) or sword sheath (Ernout and Meillet 1979; Fernandez 1999). Its function would be to store the gladius (little Roman sword). Considering that gladius was a common name for the penis, vagina became a word used to characterize the female genitalia in analogy to the joining of the penis and vagina during copulation (Ernout and Meillet 1979; Fernandez 1999). The hemipenis does not enter the UVJ in P. patagoniensis; thus, the term vagina does not apply. Although the etymology of the word uterus is uncertain, it is known that the primitive form would be the Indo-European term udero, which meaning is associated with the mother's venter and the origin of life (Ernout and Meillet 1979). Later, this term evolved to hystéra in Greek, and uterus in Latin. Other hypothesis is that the term uterus derives from uter, a recipient made of animal skin, used to transport liquids. This designation was used due to its similarity to a pregnant uterus (Fernandez 1999). Therefore, we termed this region as utero-vaginal junction because it does not house the eggs during pregnancy, but it does function as a duct or canal and as a sperm storage site. This is the first purpose for using this term in snakes.

Grossly, the vagina is easily differentiated in some snakes (Siegel and Sever 2008a, b; Siegel et al. 2011). However, in $P$. patagoniensis, the vagina is fused to the cloaca and it is not visible to the naked eye. The shape of the vagina may be linked to the shape of the male hemipenis in snakes of some lineages (Boidae, Erycidae, Phytonidae, and Scolecophidae) (Cope 1898; Pope 1941). Nevertheless, a recent analysis showed the opposite (Siegel 
et al. 2012). Moreover, the shape of the vagina is highly polymorphic within different species of a lineage (Siegel et al. 2012). The use of a correct nomenclature is based solely on the histological study of the whole oviduct aiming to differentiate its regions (Blackburn 1998). Thus, the use of equivalent terms based solely on a visual comparison of macroscopical regions may be considered with caution (Blackburn 1998). Anatomically, the oviduct of $P$. patagoniensis showed similar characteristics to other Dipsadidae species (De Resende and Nascimento 2015). However, the scarcity of morphofunctional studies on the female reproductive tract, mainly considering neotropical species, makes difficult to compare and understand the appearance and evolution of structures within this lineage.

\section{Sperm storage}

There are two major sites for sperm storage in female snakes: the posterior infundibulum and UVJ (Fox 1956; Hoffman and Wimsatt 1972; Halpert et al. 1982; Aldridge 1992; Perkins and Palmer 1996; Almeida-Santos and Salomão 1997; Sever and Ryan 1999; Siegel and Sever 2006; Barros et al. 2014a). After mating, sperm receptacles are quickly filled with spermatozoa in most snake species (Fox 1956; Hoffman and Wimsatt 1972). According to Fox (1956), the cilia of infundibular tubular glands would be responsible for a counterflow, creating a current to the oviduct lumen. Sperm would move against this current, ascending the oviduct in the direction of receptacles (Fox 1956). Another hypothesis is that the production of granules rich in neutral carbohydrates would attract sperm to receptacles (Siegel et al. 2011). The last hypothesis seems to apply to $P$. patagoniensis because histochemical reactions for PAS in SR were highly positive in the presence of spermatozoa. Some snakes- $T$. sirtalis (Hoffman and Wimsatt 1972), T. coronata (Aldridge 1992), D. punctactus (Perkins and Palmer 1996), S. pygaeae (Sever and Ryan 1999), and A. piscivorus (Siegel and Sever 2008a)—showed high positivity to PAS in the SR.

In general, stored sperm inside the SR show a parallel alignment with spermatozoa heads oriented to the epithelium of the receptacle (Siegel et al. 2011). During sperm storage in $P$. patagoniensis, we described a close contact of spermatozoa nuclei with the terminal portion of SR. This pattern has already been described in snakes of several lineages, such as Viperidae, Natricidae, and Colubridae (Fox 1956; Hoffman and Wimsatt 1972; Aldridge 1992; Sever and Ryan 1999; Siegel and Sever 2008a). Also, there are descriptions of groups of spermatozoa penetrating the secretory cells of SR in A. piscivorus (Siegel and Sever 2008a), and a possible reabsorption of sperm in $T$. sirtalis (Hoffman and Wimsatt 1972).
The expulsion of the gametes from SR to fertilize the oocytes during ovulation is still a controversial theme. The most popular hypothesis is that the mechanical force of compression caused by the passage of the oocyte would release the spermatozoa for fertilization. The presence of myoepithelial cells around SR of $P$. patagoniensis evokes different questions about its function. These cells are influenced by endocrine stimuli (hormonal), mechanical stress, and seasonal variation in morphology, like observed in the testes of some vertebrates (Unsicker and Burnstock 1975; Maekawa et al. 1996). Myoepithelial cells may contract and induce expulsion of spermatozoa from SR, but they may also act in the prevention of an excessive distension of the SR caused by an increase in luminal pressure. The presence of sperm in SR of pregnant and recently oviposited females suggests that the expulsion of gametes may be partial. More studies are needed to determine whether spermatozoa are released from SR endocrine or mechanical (or both).

This is the first report of sperm storage in the infundibulum of a neotropical snake. Barros et al. (2014b) and De Resende and Nascimento (2015) observed some glands, which they hypothesized to be sperm storage tubules (SST) in the posterior infundibulum of Bothrops erythromelas and Atractus pantostictus. However, sperm was not found in these glands, and thus, sperm storage was not confirmed at that site for these species. Results obtained for $P$. patagoniensis confirm that stored sperm may be used in more than one reproductive season, conferring a great reproductive advantage for females. Sperm disappears within the SR soon after ovulation (or after 2 months) in D. punctactus, C. cerastes, and $V$. aspis (Saint-Girons 1975; Perkins and Palmer 1996). Nevertheless, sperm remains stored for several months after ovulation in A. piscivorus and $T$. coronata (including postpartum females in A. piscivorus), but it disappears before the next mating season begins (Aldridge 1992; Siegel and Sever 2008a).

Sperm storage in the crypts of the UVJ in $P$. patagoniensis was also observed in other snakes for different periods of time, varying from a couple of weeks to a couple of months (e.g., throughout hibernation or during winter), before a subsequent migration to the infundibulum (Fox 1956; Saint-Girons 1975; Halpert et al. 1982; Aldridge 1992; Perkins and Palmer 1996). Neotropical pit vipers store sperm in the UVJ from mating in autumn through winter, until ovulation occurs in spring (Almeida-Santos and Salomão 1997, 2002; Barros et al. 2012, 2014a). It has been suggested that sperm would not remain in the crypts of the UVJ after ovulation; thus, spermatozoa would be eliminated or reabsorbed (Siegel and Sever 2008a; Siegel et al. 2011). However, the presence of stored sperm in the UVJ of pregnant females of $P$. patagoniensis (and females 
that had recently oviposited) suggests the opposite. Thereby, $P$. patagoniensis does not eliminate the sperm after ovulation and may be able to produce several clutches from a single mating by utilizing the remaining stored sperm within the UVJ.

Sperm storage in the crypts of the UVJ and infundibular receptacles shows that the oviduct of $P$. patagoniensis is highly specialized. Evolution of sperm storage in reptiles is a very controversial theme. Only two studies with similar results have focused on this question so far (Sever and Hamlett 2002; Eckstut et al. 2009). Sperm storage in the infundibular region was considered the ancestral condition for snakes in both studies. However, these analyses considered only data on sperm receptacles, ignoring data on sperm storage in the UVJ (Siegel et al. 2011). Future research on sperm storage in neotropical squamates may help to elucidate several questions related to sperm storage and reproductive cycles in squamates.

Acknowledgments The authors thank C. Jared and M. Antoniazzi for kindly allowing the use of material and equipment in the Laboratory of Cell Biology (IB). S. R. Travaglia-Cardoso and D. Maia for supplying snakes received in the IB and G. A. Cotta for access to collection of FUNED. Thanks to R. E. Grassi Ricci for help with scanning electron microscope. This study is based on a PhD thesis undertaken by Claudio A. Rojas funded by Conselho Nacional de Desenvolvimento Tecnológico e Científico-CNPQ.

\section{Compliance with ethical standards}

Conflict of interest The authors declare that they have no conflict of interest.

Ethical approval All procedures performed in studies involving animals were in accordance with the ethical standards of the institution or practice at which the studies were conducted.

\section{References}

Aldridge RD (1992) Oviductal anatomy and seasonal sperm storage in the southeastern crowned snake (Tantilla coronata). Copeia 1992:1103-1106

Aldridge RD, Duvall D (2002) The evolution of the mating season in the pitvipers of North America. Herpetol Monogr 16:1-25

Aldridge RD, Goldberg SR, Wisniewski SS, Bufalino AP, Dillman CB (2009) The reproductive cycle and estrus in the colubrid snakes of temperate North America. Contemp Herpetol 4:1-31

Almeida-Santos SM, Orsi AM (2002) Ciclo reprodutivo de Crotalus durissus e Bothrops jararaca (Serpentes, Viperidae): morfologia e função do oviduto. Rev Bras Reprod Anim 26:109-112

Almeida-Santos SM, Salomão MG (1997) Long-term sperm storage in the Neotropical rattlesnake Crotalus durissus terrificus (Viperidae: Crotalidae). Jpn J Herpetol 17:46-52

Almeida-Santos SM, Salomão MG (2002) Reproduction in neotropical pitvipers, with emphasis on species of the genus Bothrops. In: Schuett G, Höggren M, Douglas ME, Greene HW (eds) Biology of the vipers. Carmel, Eagle Mountain, pp 445-462

Bakst MR (1987) Anatomical basis of sperm-storage in the avian oviduct. Scann Microscop 1:1257-1266
Bakst MR, Bahr JM (1993) Poultry. In: Hafez ESE (ed) Reproduction in farm animals. Lea and Febiger, Philadelphia, pp 385-402

Barros VA, Sueiro LR, Almeida-Santos SM (2012) Reproductive biology of the neotropical rattlesnake Crotalus durissus from northeastern Brazil: a test of phylogenetic conservatism of reproductive patterns. Herpetol J 22:97-104

Barros VA, Rojas CA, Almeida-Santos SM (2014a) Is rainfall seasonality important for reproductive strategies in viviparous Neotropical pit vipers? A case study with Bothrops leucurus from the Brazilian Atlantic Forest. Herpetol J 24:67-75

Barros VA, Rojas CA, Almeida-Santos SM (2014b) Reproductive biology of Bothrops erythromelas from the Brazilian Caatinga. Adv Zool. doi:10.1155/2014/680861

Bauman MA, Metter DE (1977) Reproductive cycles of the northern watersnake, Natrix s. sipedon (Reptilia, Serpentes, Colubridae). J Herpetol 11:51-59

Blackburn DG (1998) Structure, function, and evolution of the oviducts of squamate reptiles, with special reference to viviparity and placentation. J Exp Zool 282:560-617

Callard IP, Bayne CG, McConnell WF (1972) Hormones and reproduction in the female lizard Sceloporus cyanogenys. Gen Comp Endocrinol 18:175-194

Carretero MA (2006) Reproductive cycles in Mediterranean lacertids: plasticity and constraints. In: Corti C, Lo Cascio P, Biaggini (eds) Mainland and insular lacertid lizards: a mediterranean perspective. Firenze University Press, Florence, pp 33-54

Cope ED (1898) The crocodilians, lizards and snakes in North America. Rep US Natl 18:155-1270

Corso G, Pala M, Pinna AM, Carcupino M (1988) Aspetti morfofunzionali delĺoviducto di Chalcides ocellatus tiligugu Gmelin (Squamata, Scincidae). Arch Ital Anat Embriol 93:237-251

De Resende FC, Nascimento LB (2015) The female reproductive cycle of the neotropical snake Atractus pantostictus (Fernandes and Puorto, 1993) from South-eastern Brazil. Anat Histol Embryol 44:225-235

Eckstut ME, Sever DM, White ME, Crother BI (2009) Phylogenetic analysis of sperm storage in female squamates. In: Dahnof LT (ed) Animal reproduction: new research developments. Nova Science Publishers, New York, pp 185-218

Ernout A, Meillet A (1979) Dictionnaire étymologique de la langue latine, 4th edn. Klincksieck, París

Fernandez GSM (1999) Eponímia e etimologia. Editora Plêiade, São Paulo

Fowler IR, Salomão MG, Jordão RSA (1998) A description of the female reproductive cycle in four species from the neotropical colubrid snake Philodryas (Colubridae, Xenodontinae). The snake 28:71-78

Fox W (1956) Seminal receptacles of snakes. Anat Rec 124:519-539

Fox W (1963) Special tubules for sperm storage in female lizards. Nature 198:500-501

Gabe M, Saint-Girons H (1965) Contribution à la morphologie comparée du cloaque et des glandes épidermoïdes de la région cloacale chez les lépidosauriens. Mém Mus Natl Hist Nat 23:149-332

Garda AA, Costa GC, França FGR, Giugliano LG, Leite GS, Mesquita DO, Nogueira C, Tavares-Bastos L, Vasconcellos MM, Vieira GHC, Vitt LJ, Werneck FP, Wiederhecker HC, Colli GR (2012) Reproduction, Body Size, and Diet of Polychrus acutirostris (Squamata: Polychrotidae) in Two Contrasting Environments in Brazil. J Herpetol 46:2-8

Giacomini E (1893) Sullovidutto del Sauropsidi. Monit Zool Ital 4:202-265

Giraudo AR, Scrocchi G (2002) Argentinean snakes: an annotated checklist. Smithsonian Herpetological Information Service SHIS132, 1-53 
Girling JE (2002) The reptilian oviduct: a review of structure and function and directions for future research. J Exp Zool 293:141-170

Gist DH, Congdon JD (1998) Oviductal sperm storage as a reproductive tactic of turtles. J Exp Zool 282:526-534

Gist DH, Jones JM (1989) Sperm storage within the oviduct of turtles. J Morphol 199:379-384

Halpert AP, Garstka WR, Crews D (1982) Sperm transport and storage and its relation to the annual sexual cycle of the female red-sided garter snake, Thamnophis sirtalis parietalis. J Morphol 174:149-159

Heulin B, Stewart JR, Surget-Groba Y, Bellaud P, Jouan F, Lancien G, Deunff J (2005) Development of the uterine shell glands during the preovulatory and early gestation periods in Oviparous and Viviparous Lacerta vivipara. J Morphol 266:80-93

Hoffman LH (1970) Placentation in the garter snake Thamnophis sirtalis. J Morphol 131:57-88

Hoffman LH, Wimsatt WA (1972) Histochemical and electron microscopic observations on the sperm receptacles in the garter snake oviduct. Am J Ana 134:71-96

Junqueira LCU (1995) Histology revisited-technical improvement promoted by the use of hydrophilic resin embedding. Ciên Cult 47:92-95

Junqueira CL, Carneiro J (2008) Histologia básica, 11th edn. Guanabara Koogan SA, Rio de Janeiro

Junqueira LCU, Bignolas G, Brentani R (1979) Picrosirius staining plus polarization microscopy, a specific method for collagen detection in tissue sections. Histochem J 11:447-455

Ludwig M, Rahn H (1943) Sperm storage and copulatory adjustment in the prairie rattlesnake. Copeia 1:15-18

Maekawa M, Kamimura K, Nagano T (1996) Peritubular myoepithelial cells in the testis: their structure and function. Arch Histol Cytol 59:1-13

Marinho CE, Almeida-Santos SM, Yamasaki SC, Silveira PF (2009) Peptidase activities in the semen from the ductus deferens and uterus of the neotropical rattlesnake Crotalus durissus terrificus. J Comp Physiol B 179:635-642

Mead RA, Eroschenko VP, Highfill DR (1981) Effects of progesterone and estrogen on the histology of the oviduct of the garter snake, Thamnophis elegans. Gen Comp Endocrinol 45:345-354

Mesquita DO, Colli GR (2003) Geographical Variation in the Ecology of Populations of Some Brazilian Species of Cnemidophorus (Squamata, Teiidae). Copeia 2:285-298

Panigel M (1956) Contribution a l'étude de l'ovoviviparité chez les reptiles: gestation et parturition chez le lézard vivipare Zootoca vivipara (XI). Ann Sci Nat Zool Biol Anim 18:569-668

Perkins MJ, Palmer BD (1996) Histology and functional morphology of the oviduct of an oviparous snake, Diadophis punctatus. J Morphol 227:67-79

Pope CH (1941) Copulatory adjustment in snakes. Zool Ser Field Mus Nat Hist 24:249-252
Ribeiro LB, Kolodiuk MF, Freire EMX (2010) Ventral colored patches in Tropidurus semitaeniatus (Squamata, Tropiduridae): sexual dimorphism and association with reproductive cycle. J Herpetol 44:177-182

Rojas CA, Barros VA, Almeida-Santos SM (2013) The reproductive cycle of the male sleep snake Sibynomorphus mikanii (Schlegel, 1837) from southeastern Brazil. J Morphol 274:215-228

Saint-Girons H (1957) Le cycle sexuel chez Vipera aspis dans louest de la France. Bull Biol Fr Belg 91:284-350

Saint-Girons H (1962) Presence de receptacles seminaux chez les cameleons. Beaufortia 9:165-172

Saint-Girons H (1975) Sperm survival and transport in the female genital tract of reptiles. In: Hafez ESE, Thibault CG (eds) The Biology of Spermatozoa. S. Karger, Basel, pp 106-113

Sanchez-Martínez PM, Ramírez-Pinilla MP, Miranda-Esquivel D (2007) Comparative histology of the vaginal-cloacal region in Squamata and its phylogenetic implications. Acta Zool-Stockholm 88:289-307

Sever DM, Hamlett WC (2002) Female sperm storage in reptiles. J Exp Zool 187:187-199

Sever DM, Ryan TJ (1999) Ultrastructure of the reproductive system of the black swamp snake (Seminatrix pygaea): part I. Evidence for oviductal sperm storage. J Morphol 241:1-18

Sever DM, Ryan TJ, Morris T, Patton D, Swafford S (2000) Ultrastructure of the reproductive system of the black swamp snake (Seminatrix pygaea): part II. The annual oviductal cycle. J Morphol 245:146-160

Siegel DS, Sever DM (2006) Uterine-muscular twisting and sperm storage in viperids. Herpetol Conserv Biol 1:87-92

Siegel DS, Sever DM (2008a) Sperm aggregations in female Agkistrodon piscivorus (Reptilia; Squamata): a histological and ultrastructural investigation. J Morphol 269:189-206

Siegel DS, Sever DM (2008b) Seasonal variation in the oviduct of female Agkistrodon piscivorus (Reptilia: Squamata): an Ultrastructural investigation. J Morphol 269:980-997

Siegel DS, Miralles A, Chabarria RE, Aldridge RD (2011) Female reproductive anatomy: cloaca, oviduct, and sperm storage. In: Aldridge RD, Sever DM (eds) Reproductive biology and phylogeny of snakes. CRC Press, Enfield, pp 347-409

Siegel DS, Miralles A, Trauth SE, Aldridge RD (2012) The phylogenetic distribution and morphological variation of the 'pouch' in female snakes. Acta Zool 93:400-408

Thomas RA (1976) A revision of the South American colubrid snake genus Philodryas Wagler, 1830. Ph.D. Thesis, University College Station, Texas

Unsicker K, Burnstock G (1975) Myoid cells in the peritubular tissue (Lamina propria) of the reptilian testis. Cell Tissue Res 163:545-560

Uribe MCA, González-Porter G, Palmer BD, Guillette LJ (1998) Cyclic histological changes of the oviductal-cloacal junction in the viviparous snake Toluca lineata. J Morphol 237:91-100 